\title{
Proximate and heavy metals composition of Plantain (Musa paradisiaca L.) fruits harvested from some solid waste dumps in Uyo Metropolis, Nigeria
}

\author{
Iniobong E. Okon*, Uduakobong E. Akwaowo
}

Department of Botany \& Ecological Studies, University of Uyo, Nigeria.

\begin{abstract}
Plantain thrives well in waste dumpsites. These wastes usually contaminate the soil with heavy metals which become absorbed by the plants. The risk of heavy metal toxicity in humans is an issue of serious concern globally. Proximate composition of plantain fruits harvested from three randomly selected waste dumpsites in Uyo metropolis, Nigeria were determined using AOAC standard analytical techniques while their heavy metals ( $\mathrm{Pb}, \mathrm{Cr}, \mathrm{Ni}, \mathrm{Cu}, \mathrm{Co}, \mathrm{Cd}$ and As) concentrations and that of their rhizosphere soil were analysed with Unicam Atomic Absorption Spectrophotometer. Proximate analyses results revealed that carbohydrate content was higher in the fruits harvested from the control uncontaminated soil sites $(91.61 \%)$ than in the fruits harvested from dumpsite soils (87.23\%; 87.89\%; 88.00\%). Dumpsite soils had higher heavy metals concentrations than the control soil. Lead $(\mathrm{Pb})$ was the highest occurring heavy metal in all the dumpsite soils. Fruits harvested from the dumpsite soils had higher heavy metals concentrations than those from the control soil. $\mathrm{Pb}$ was the only heavy metal whose concentration in the plantain fruits was higher than the WHO/FAO permissible limit. This work has established that the selected dumpsite soils have been contaminated with heavy metals which have been absorbed by the plantain cultivated there. Cultivation and consumption of plantain from these dumpsite soils should be discouraged.
\end{abstract}

Keywords - Dumpsites soils, Heavy metals, Plantain fruits, Proximate composition.

\section{INTRODUCTION}

Plantain (Musa paradisiaca L.) is a tree-like herb belonging to the Musaceae family. With its high starchy fruits, plantain fruit serves as a staple crop in most parts of the tropics including Nigeria. Plantain fruits have high fibre contents which make it a diet for lowering of blood cholesterol and relieving of constipation thereby putting colon cancer at bay (Okareh, 2015). Plantain has a high demand for organic matter and thrives luxuriantly in waste dumpsites where they produce healthy bunches of fruits.

Solid waste dumpsites are common features in most urban cities in Nigeria as much waste is generated by their teeming human population. Due to scarcity of arable lands in the urban areas, plantain is cultivated in strategic locations where all sorts of solid waste materials are dumped. Leachates from these dumpsites contribute heavy metals to the soil (Ukpong et al., 2013) which according to Ideria et al. (2010) constitute the commonest occurring group of solid waste dumpsite soil contaminants. Plantain growing in such dumpsites absorbs these heavy metals along with other nutrients and accumulates them in its fruits. Studies have revealed higher levels of heavy metals such as lead, cadmium, nickel, cobalt, arsenic and chromium in waste dumpsite soils than in soil some distances away from them (Ukpong et al., 2013; AmosTautua et al., 2014; Olufunmilayo et al., 2014, Tanee and Eshalomi-Mario, 2015). Higher concentrations of these heavy metals have also been detected in fruits and vegetables harvested from waste dumpsites (Imasuen Omorogieva, 2013; Cortez and Ching, 2014; Tanee and Eshalomi-Mario, 2015).

Heavy metals according to Kibria et al. (2010) are elements with an atomic weight greater than 20 and are characterised by similar atomic electronic configurations in the outer orbitals. They are mostly harmful chemicals as they are usually persistent, toxic and bio-accumulative in the environment while some of them are also endocrine disrupting as well as carcinogenic (Kibria et al. 2016a; Kibria et al. 2016b). Some heavy metals such as iron, nickel, zinc, copper are known to be essential and beneficial for the growth and development of plants and animals 
including humans at low concentrations (Cortez and Ching, 2014; Tanee and Eshalomi-Mario, 2015; Balkhair and Ashraf, 2016). Other heavy metals such as lead, cadmium and mercury are highly toxic even at low concentrations (Cortez and Ching, 2014).

The issue of heavy metals contamination of soil and subsequent uptake and accumulation in food crops is fast becoming a major health concern as their presence pose serious health hazards to plants, animals and humans (RimRukeh, 2012). The danger posed by the presence of heavy metals such as arsenic (As), cadmium (Cd), chromium (Cr), cobalt $(\mathrm{Co})$, copper $(\mathrm{Cu})$, lead $(\mathrm{Pb})$ and nickel $(\mathrm{Ni})$ is as a result of their bioaccumulation in the environment with time (Helmenstine, 2014). Prolonged intake of heavy metals contaminated food is implicated with cancer, nervous system disorders, cardiovascular diseases, renal problems, destruction of liver, lungs and kidneys. The risk involved in consuming crops harvested from waste dumpsites calls for serious investigation into the concentration of heavy metals in such food items. This research was therefore carried out to investigate the heavy metals $(\mathrm{Pb}, \mathrm{Cr}, \mathrm{Ni}, \mathrm{Cu}, \mathrm{Co}, \mathrm{Cd}$ and As) concentrations of both the dumpsite soils and their plantain fruits as well as the possible effect on the proximate composition of such fruits. Findings from this work are expected to give growers of plantain on dumpsite soils insight as to the risk of heavy metals accumulation in the fruits and the consequent health hazards to their consumers.

\section{MATERIALS AND METHODS}

\section{Sampling Site}

Three dumpsites cultivated with plantain bearing mature unripe bunches of fruits located within Uyo metropolis were randomly selected. Fruits for control were harvested from another location without any waste dumpsite within the same metropolis. The geographical coordinates of Uyo is $5^{\circ}$ 3' 0" North and 7 ${ }^{\circ}$ 56' $0^{\prime \prime}$ (maplandia.com, 2016). The experimental sites as determined using a Global positioning system (GPS) to geo-reference the sampling positions were respectively designated as: Site A located between latitude $5^{\circ} 11^{\prime} 56.935^{\prime \prime N}$ and longitude $7^{\circ} 55^{\prime} 46.714 " E$; Site B located between latitude $5^{\circ} 1^{\prime} 21.640^{\prime \prime} \mathrm{N}$ and longitude 7०54'47.592"E; Site C located between latitude $5^{\circ} 0^{\prime} 35.8812^{\prime \prime} \mathrm{N}$ and longitude $7^{\circ} 55^{\prime} 5.4048^{\prime \prime} \mathrm{E}$ and the Control site located between latitude $4^{\circ} 59^{\prime} 7.224^{\prime \prime} \mathrm{N}$ and longitude 755'11.244"E.

\section{Collection of Plant and Soil Samples.}

Rhizosphere soil samples were collected in triplicates from each site at $15-20 \mathrm{~cm}$ rooting zone using soil auger. The plantain fruits were also collected in triplicates from plants whose rhizosphere soil samples were collected. The soil and plant samples were appropriately labeled and taken to the laboratory for proximate and heavy metal analyses.

\section{Preparation of the plantain fruit samples.}

Each batch of fruits from each dumpsite was separately washed with distilled water and peeled. They were then cut into thin slices and air dried at room temperature before being transferred to an oven (Gallenkamp) to dry at $80^{\circ} \mathrm{C}$. The dried slices were then ground into powder using an electric blender (Model: GND-280 AUTOSHARP) and stored in an airtight container until when needed for analysis.

\section{Proximate composition analysis of plantain fruits}

The proximate nutrient composition of the plantain fruits was determined using the standard methods of analysis of Association of Official Analytical Chemists (AOAC, 2000) for moisture, dry matter, crude protein, lipid, ash and fibre. Moisture content was determined by drying in a (Gallenkamp) oven at $105^{\circ} \mathrm{C}$ to constant dry weight and then calculating the percentage difference between the initial and final weights. The crude protein of the samples was determined using micro-Kjeldahl method. Percentage lipid content was determined using petroleum ether (B.P. $60^{\circ} \mathrm{C}-80^{\circ} \mathrm{C}$ ) extraction by reflux Soxhlet method and the percentage oil calculated as:

$$
\% \text { Oil }=\frac{\text { Weight of oil } \times 100}{\text { Weight of dry sample }}
$$

Ash content was determined by dry ashing in a muffle furnace at $550^{\circ} \mathrm{C}$ until grayish white ash was obtained and calculating the percentage difference between the sample initial weight and the ash weight. Crude fibre was determined using acid-base digestion with $1.25 \% \mathrm{H}_{2} \mathrm{SO}_{4}$ (w/v) and $1.25 \% \mathrm{NaOH}(\mathrm{w} / \mathrm{v})$ solutions. Carbohydrate content was obtained following Onwuka (2005) method as the difference:

$\%$ Carbohydrate $=100-(\%$ crude protein $+\%$ crude fibre + $\%$ ash $+\%$ crude fat).

\section{Determination of heavy metals contents in the plant samples}

The powdered plant samples were ashed in a muffle furnace and digested after the procedure of Adefemi et al. (2012). $2 \mathrm{~g}$ of each ashed plant sample was digested in $15 \mathrm{ml}$ of $\mathrm{HNO}_{3}$ at $80^{\circ} \mathrm{C}$ until a transparent solution was obtained. The solution was allowed to cool and then filtered through Whatman filter paper (no. 42) into $100 \mathrm{ml}$ volumetric flask and made to mark with distilled water. Each filtrate was 
stored in separately labeled sample bottle ready for the determination of $\mathrm{Pb}, \mathrm{Cr}, \mathrm{Ni}, \mathrm{Cu}, \mathrm{Co}, \mathrm{Cd}, \mathrm{As}$ and $\mathrm{Fe}$ concentrations using Unicam 939 atomic absorption spectrophotometer (AAS). The AAS was calibrated with appropriate standard solutions for each element and the samples filtrate were aspirated in turns into it to determine the heavy metals concentration.

\section{Determination of heavy metals contents in the soil samples.}

Determination of heavy metals concentration of the soil samples was carried out using the method of Cortez and Ching (2014). Each soil sample was oven-dried at $105^{\circ} \mathrm{C}$, ground with mortar and pestle and sieved through a $2 \mathrm{~mm}$ sieve. About $0.5 \mathrm{~g}$ of each sample was weighed into a porcelain crucible and ignited at $450^{\circ} \mathrm{C}$ in a furnace to destroy organic matter, then digested twice with $10 \mathrm{ml}$ of a mixture of 1:1 mixture of concentrated $\mathrm{HNO}_{3}$ and $\mathrm{HF}$ in a $100 \mathrm{ml}$ polyprylene beaker and placed over a water bath for evaporation till dryness. The residue was dissolved in $20 \mathrm{ml}$ of $2 \mathrm{M} \mathrm{HNO}_{3}$ and diluted to mark in $100 \mathrm{ml}$ volumetric flask. The digest was then used for heavy metals $(\mathrm{Pb}, \mathrm{Cr}$, $\mathrm{Ni}, \mathrm{Cu}, \mathrm{Co}, \mathrm{Cd}$ and $\mathrm{As}$ ) concentrations determination using Unicam 939 model of atomic absorption spectrophotometer (AAS).

Table.1: Proximate composition of plantain fruits (\%)

\begin{tabular}{lllll}
\hline Parameters & Site A & Site B & Site C & Control \\
\hline Moisture content & $* 51.28 \mathrm{~b}$ & $53.27 \mathrm{a}$ & $54.00 \mathrm{a}$ & $51.00 \mathrm{~b}$ \\
Dry matter & $48.72 \mathrm{a}$ & $46.73 \mathrm{a}$ & $46.00 \mathrm{a}$ & $49.00 \mathrm{a}$ \\
Crude protein & $7.88 \mathrm{a}$ & $7.77 \mathrm{a}$ & $7.69 \mathrm{a}$ & $3.76 \mathrm{~b}$ \\
Crude fat & $1.10 \mathrm{a}$ & $0.070 \mathrm{c}$ & $0.88 \mathrm{~b}$ & $0.93 \mathrm{a}$ \\
Crude fibre & $0.30 \mathrm{a}$ & $0.22 \mathrm{~b}$ & $0.26 \mathrm{ab}$ & $3.04 \mathrm{a}$ \\
Ash content & $3.50 \mathrm{a}$ & $3.30 \mathrm{a}$ & $2.28 \mathrm{~b}$ & $3.04 \mathrm{a}$ \\
Carbohydrate & $87.23 \mathrm{~b}$ & $88.00 \mathrm{~b}$ & $87.89 \mathrm{~b}$ & $91.61 \mathrm{a}$ \\
\hline
\end{tabular}

*Means of three replicates. Mean within each row followed by different letters are significantly different at $\mathrm{P}=0.05$ according to Duncan's multiple range test.

Dumpsite soil heavy metals analyses as presented in Table 2 showed that the control site soil had significantly $(\mathrm{P}=0.05)$ lower heavy metal contents for $\mathrm{Pb}, \mathrm{Cr}, \mathrm{Ni}, \mathrm{Co}$, and $\mathrm{Cd}$ and significantly $(\mathrm{P}=0.05)$ higher $\mathrm{Cu}$ and $\mathrm{As}$ contents than the were used in calculating the accumulation factor as the ratio of heavy metal concentration in the plantain fruit to the heavy metal concentration in their corresponding rhizosphere soil for samples from each site (Li et al., 2012):

AF

$=\frac{\text { Heavy metal concentration in the food crops edible parts }}{\text { Heavy metal concentration in the soil }}$ All data generated in triplicates were subjected to analysis of variance using SPSS for windows version 19. Means were separated using Duncan's multiple range test.

\section{RESULTS}

The proximate composition of plantain fruits harvested from the different dumpsites in Uyo metropolis under investigation and that of the control is as presented in Table 1. Carbohydrate $(91.61 \%)$ content was significantly $(\mathrm{P}=$ 0.05) higher in control site fruits than in dumpsites fruits. Crude protein on the other hand was significantly $(\mathrm{P}=0.05)$ lowest $(3.76 \%)$ in control site fruits. Crude lipid was significantly higher $(1.10 \%)$ in fruits from dumpsite A than other sites.
Heavy metals concentration data from the soil and fruits dumpsite soils. The highest $\mathrm{Cr}, \mathrm{Ni}, \mathrm{Co}$ and $\mathrm{Cd}$ contents were recorded from dumpsite $\mathrm{A}$ while the highest $\mathrm{Pb}$ content was from dumpsite B.

Table.2: Concentration of heavy metals in Dumpsite Soil samples ( $\mathrm{mg} / \mathrm{kg}$ ) compared with WHO/FAO certified standards.

\begin{tabular}{llllll}
\hline Heavy Metal & Site A & Site B & Site C & Control & ${ }^{\S}$ WHO/FAO \\
$\mathrm{Pb}$ & $* 18.29 \mathrm{~b}$ & $21.18 \mathrm{a}$ & $20.32 \mathrm{a}$ & $5.56 \mathrm{c}$ & 100.00 \\
$\mathrm{Cr}$ & $10.56 \mathrm{a}$ & $9.89 \mathrm{a}$ & $8.54 \mathrm{~b}$ & $5.88 \mathrm{c}$ & 100.00 \\
$\mathrm{Ni}$ & $7.05 \mathrm{a}$ & $6.64 \mathrm{~b}$ & $6.16 \mathrm{c}$ & $6.06 \mathrm{c}$ & 50.00 \\
$\mathrm{Cu}$ & $2.34 \mathrm{~b}$ & $2.21 \mathrm{~b}$ & $1.65 \mathrm{c}$ & $5.11 \mathrm{a}$ & 10.00 \\
\hline
\end{tabular}




$\begin{array}{llllll}\text { Co } & 1.42 \mathrm{a} & 1.38 \mathrm{a} & 1.29 \mathrm{~b} & 0.20 \mathrm{c} & 50.00 \\ \mathrm{Cd} & 1.55 \mathrm{a} & 1.51 \mathrm{a} & 1.46 \mathrm{a} & 1.20 \mathrm{~b} & 3.00 \\ \mathrm{As} & <0.01 \mathrm{~b} & <0.01 \mathrm{~b} & <0.02 \mathrm{~b} & <0.05 \mathrm{a} & 20.00\end{array}$

* Means of three replicates. Mean within each row followed by different letters are significantly different at $\mathrm{P}=0.05$ according to Duncan's multiple range test. ${ }^{\S}$ Maximum allowable limits of heavy metal in soils as defined by WHO and FAO. (Chiroma et al., 2014).

Concentration of heavy metals in fruits was significantly $(\mathrm{P}=0.05)$ lower in samples from the control site than fruits from dumpsite soils (Table 3).

Table.3: Concentration of heavy metals in Dumpsite Fruits samples $(\mathrm{mg} / \mathrm{kg})$ compared with certified standards.

\begin{tabular}{llllll}
\hline Metal & Site A & Site B & Site C & Control & ${ }^{\S}$ WHO/FAO \\
$\mathrm{Pb}$ & ${ }^{*} 8.67 \mathrm{a}$ & $8.52 \mathrm{a}$ & $7.63 \mathrm{~b}$ & $1.13 \mathrm{c}$ & 0.30 \\
$\mathrm{Cr}$ & $7.44 \mathrm{a}$ & $7.33 \mathrm{a}$ & $6.59 \mathrm{~b}$ & 2.23 & - \\
$\mathrm{Ni}$ & $3.36 \mathrm{a}$ & $2.85 \mathrm{~b}$ & $2.66 \mathrm{~b}$ & $1.14 \mathrm{c}$ & 67.00 \\
$\mathrm{Cu}$ & $5.26 \mathrm{a}$ & $3.66 \mathrm{~b}$ & $2.44 \mathrm{c}$ & $0.02 \mathrm{~d}$ & 73.00 \\
$\mathrm{Co}$ & $1.36 \mathrm{a}$ & $1.28 \mathrm{a}$ & $1.25 \mathrm{a}$ & ND & 50.00 \\
$\mathrm{Cd}$ & $0.32 \mathrm{a}$ & $0.29 \mathrm{a}$ & $0.22 \mathrm{~b}$ & ND & 0.10 \\
$\mathrm{As}$ & $<0.02 \mathrm{a}$ & $<0.02 \mathrm{a}$ & $<0.02 \mathrm{a}$ & ND & - \\
\hline
\end{tabular}

-Means of three replicate. Mean within each row followed by different letters are significantly different at $\mathrm{p}=0.05$ according to Duncan's Multiple range test. ${ }^{\S}$ Maximum allowable limits of heavy metal in plant as defined by WHO and FAO (Chiroma et al., 2014).

Accumulation factor calculations (Table 4) showed the highest values for $\mathrm{Cu}(2.25)$ in dumpsite $\mathrm{A}$, followed by $\mathrm{As}$ (2.00) in dumpsites $\mathrm{A}$ and B. Accumulation factor was generally low in the control site fruits for all heavy metals than those from the dumpsites.

Table.4: Accumulation Factor of heavy metals in the experimental sites

\begin{tabular}{ccccc}
\hline Heavy Metal & Site A & Site B & Site C & Control \\
$\mathrm{Pb}$ & $* 0.47 \mathrm{a}$ & $0.40 \mathrm{bc}$ & $0.38 \mathrm{c}$ & $0.20 \mathrm{~d}$ \\
$\mathrm{Cr}$ & $0.70 \mathrm{c}$ & $0.74 \mathrm{ab}$ & $0.77 \mathrm{a}$ & $0.38 \mathrm{~d}$ \\
$\mathrm{Ni}$ & $0.48 \mathrm{a}$ & $0.43 \mathrm{~b}$ & $0.43 \mathrm{~b}$ & $0.19 \mathrm{c}$ \\
$\mathrm{Cu}$ & $2.25 \mathrm{a}$ & $1.66 \mathrm{~b}$ & $1.48 \mathrm{~b}$ & $0.01 \mathrm{c}$ \\
$\mathrm{Co}$ & $0.96 \mathrm{a}$ & $0.93 \mathrm{a}$ & $0.97 \mathrm{a}$ & $0.00 \mathrm{~b}$ \\
$\mathrm{Cd}$ & $0.21 \mathrm{a}$ & $0.19 \mathrm{ab}$ & $0.15 \mathrm{~b}$ & $0.00 \mathrm{c}$ \\
$\mathrm{As}$ & $2.00 \mathrm{a}$ & $2.00 \mathrm{a}$ & $1.00 \mathrm{~b}$ & $0.00 \mathrm{c}$ \\
\hline
\end{tabular}

${ }^{*}$ Means of three replicates. Mean within each row followed by different letters are significantly different at $\mathrm{P}=0.05$ according to Duncan's multiple range test.

\section{DISCUSSION}

The proximate composition (\% dry matter) of plantain fruits from both the waste dump and control soils differed from what has been reported by some earlier workers for crude protein $(5.09-5.18 \%)$, fats $(0.47-0.62 \%)$ and ash (2.03$2.33 \%$ ) while carbohydrate content was however similar to some of the results (Odenigbo et al., 2013). However, related work by Oko et al. (2015), gave lower carbohydrate contents $(70.88-81.18 \%)$ than ours, also fibre and ash contents were higher in our control samples $(3.04 \%$ and $3.04 \%)$ than what were obtained by them $(0.19-0.16 \%$ and $0.55-2.53 \%)$ respectively. The variation in the nutrient composition of our results as compared to those of other workers could probably have been due to the differences in their growth environment, soil properties, varietal differences and even the prevailing climate. (Koyuncu et al., 2014; Zou et al., 2015). Carbohydrate and fibre contents were significantly highest in the control soil fruit samples. Unripe plantain fruits are known to be high in carbohydrate contents (Makanjuola et al., 2013). Carbohydrates are energy yielding food nutrients. Thus plantain fruits harvested from uncontaminated soil will supply enough energy to the consumer. Dietary fibre such as contained in unripe plantain fruits has been implicated with such health 
benefits as reducing blood cholesterol, slowing the rate of glucose absorption, improving the sensitivity of the body to insulin, relieving constipation and preventing the incidence of colon cancer (Okareh et al., 2015; Oko et al., 2015).

With the exception of $\mathrm{Cu}$ and $\mathrm{As}$, all the other heavy metals investigated showed significantly higher concentrations in the dumpsite soil samples than in the control. The heavy metals concentrations in the dumpsite soil samples were lower for $\mathrm{Cd}, \mathrm{Cu}$, and $\mathrm{Pb}$ than the mean obtained by Olufunmilayo et al. (2014) which ranged from 2.25 - 2.58; $2.58-3.30$ and $60.00-91.67 \mathrm{mg} / \mathrm{kg}$ respectively. The concentrations of $\mathrm{Co}$ and $\mathrm{Ni}$ were however higher in our results than theirs which ranged between $0.42-0.72 \mathrm{mg} / \mathrm{kg}$ and $1.91-2.91 \mathrm{mg} / \mathrm{kg}$ respectively but our cobalt concentration was far lower than the values obtained by Awokunmi et al. (2010) which was $105-810 \mathrm{mg} / \mathrm{kg}$. Heavy metals concentrations in any soil is known to be related to the biogeochemical cycles resulting from the anthropogenic activities such as agricultural, industrial and domestic wastes disposal (Olufunmilayo et al., 2014). The highest concentrations of $\mathrm{Cr}, \mathrm{Ni}, \mathrm{Co}$ and $\mathrm{Cd}$ were detected in soil samples from dumpsite A which is an age long dumpsite fed with various kinds of wastes from a popular Uyo urban market. The occurrence of these heavy metals in the soil makes them available for absorption by the plants roots (Okoronkwo et al., 2015).

Heavy metals concentrations in plantain fruits varied markedly between those harvested from dumpsites and those from the control site. All the dumpsite fruits had significantly $(\mathrm{P}=0.05)$ higher heavy metals contents than those from the control site. Our results for $\mathrm{Pb}, \mathrm{Cr}, \mathrm{Ni}, \mathrm{Cd}$ and As were however lower than what were obtained by Imasuen and Omorogieva (2013) 10.69; 37.71; 9.18; 21.90 and $13.20 \mathrm{mg} / \mathrm{kg}$ respectively for plantain fruits harvested from different types of polluted soils. Although with the exception of $\mathrm{Pb}$ in fruit samples from dumpsites $\mathrm{B}$ and $\mathrm{C}$, the concentrations of all the other heavy metals in fruit samples were below the WHO/FAO maximum allowable limit. It is however worthy of note that their continuous consumption can lead to bioaccumulation resulting in lethal concentrations in the body. Lead is known to be very toxic even at very low concentrations (Okorononkwo et al., 2005). It is a deadly carcinogen and is associated with renal tumour, cardiovascular, kidney, nervous, circulatory, skeletal and reproductive systems damages (Kibria, 2016). $\mathrm{Cr}$ is known to be both mutagenic and carcinogenic (Podsiki, 2008), causing asthma and shortness of breath as well as liver and kidneys damage with long term exposure. $\mathrm{Ni}$ is also a human carcinogen and constitutes a health hazard at high doses causing cancer of the nose, larynx, lungs and that of the prostrate, respiratory failure, birth defects and heart disorders (Kibria, 2016). $\mathrm{Cu}$ is considered as an essential trace element for humans, but at elevated concentrations such as result from bioaccumulation, it can cause cirrhosis of the liver and results in death in extreme cases (Nolan, 2003; Kibria, 2016). Co occurs as heavy metal in the plant or animal bodies without being biomagnified up in the food chain due to the fact that a vast quantity of it ingested is passed out of the body unabsorbed (Lenntech, 2014). However, when a high concentration of Co is taken health effects such as nausea and vomiting, vision problems, heart and pulmonary problems and thyroid damage usually result (Lenntech, 2014). Cd is a toxic heavy metal even at low concentrations and is also considered a carcinogen causing bronchitis, emphysema and alveolitis (Kabata-Pendias, 2011). Arsenic is a deadly heavy metal which is considered a human carcinogen even at extremely low levels of exposure (ATSDR, 1999) with various other clinico-pathological conditions such as cardiovascular and peripheral vascular disease, developmental anomalies, neurologic and neurobehavioural disorders, diabetes, hearing loss, portal fibrosis, hematologic disorders (anemia, leukopenia and eosinophilia) carcinoma, nausea, vomiting, abdominal pain, muscle cramps and diarrhoea when taken in high concentrations (ATSDR,2000; Abdul et al., 2015).

The accumulation factor (AF) calculations showed values greater than 1 for $\mathrm{Cu}$ in fruit samples from all the dumpsites while this was the case for As only for fruit samples from dumpsites A and B. Heavy metals are capable of moving from the soil to the edible parts of the food crop ( $\mathrm{Li}$ et al., 2012). Our results showed that the accumulation factor varied with the heavy metals thus agreeing with the findings of Adefemi et al., (2012). Cu had the highest accumulation factor except in samples from the control site while $\mathrm{Cd}$ had the lowest. Those heavy metals with high AF point to the fact that much consumption of the plantain fruits from those dumpsites with time may result in some health problems.

\section{CONCLUSIONS}

The concentrations of $\mathrm{Pb}, \mathrm{Cr}, \mathrm{Ni}, \mathrm{Co}$ and $\mathrm{Cd}$ were higher in all the dumpsite soils than in the control soil. Plantain fruits from dumpsite soils accumulated higher heavy metal concentrations than those from the control soil. In the three dumpsite soils investigated, $\mathrm{Pb}$ concentration was highest followed by $\mathrm{Cr}$, while $\mathrm{Cu}$ and $\mathrm{Ni}$ followed in that order in site $\mathrm{A}$ and $\mathrm{B}$. In site $\mathrm{C}$, $\mathrm{Ni}$ was however, higher in concentration than $\mathrm{Cu}$. The presence of these heavy metals in the dumpsite soils and their accumulation in the plantain 
fruits harvested from there is sounding a cautionary note as to the health risk involved in continual cultivation and consumption of plantain fruits from these dumpsites. Proper and safer methods should be adopted by the Uyo municipal government to evacuate and dispose these wastes away from the immediate human settlement while at the same time creating awareness and discouraging the people from cultivating on waste dumpsite soils.

\section{ACKNOWLEGMENT}

The authors are grateful to the laboratory staff of Soil Science Department, University of Uyo for their technical assistance.

\section{REFERENCES}

[1] Abdul, K. S., Jayasinghe, S. S., Chandana, E. P., Jayasumana, C. and De Silva, P. M. (2015). Arsenic and human health effects: A review. Environmental Toxicology and Pharmacology, 40, 828 - 846.

[2] Adefemi, O. S., Ibigbami, O. A. and Awokunmi, E. E. (2012) Level of heavy metals in some edible plants collected from selected dumpsites in Ekiti State, Nigeria. African Journal of Environmental Science and Technology, 3, 186-189.

[3] Amos-Tautua, M. W., Onigbinde, A, O. and Ere, D. (2014). Assessment of some heavy metals and physico-chemical properties in surface soils of municipal open waste dumpsite in Yenagoa, Nigeria. African Journal of Environmental Science and Technology, 8, 41-47.

[4] AOAC (Association of official analytical chemists). (2000). Official methods of analysis of AOAC international. 17th Edn., Washington DC, USA.

[5] ATSDR (Agency for Toxic Substances and Disease Registry). (1999). Lead: Toxicological Profiles; Centers for Disease Control and Prevention: Atlanta, GA, USA, 1999.

[6] ATSDR (Agency for Toxic Substances and Disease Registry). (2000). Toxicological profile for arsenic TP- 92/09. Georgia: Center for Disease Control, Atlanta.

[7] Awokunmi, E. E., Asaolu, S. S.and Ipinmoroti, K. O. (2010) Effect of leaching on heavy metals concentration of soil in some dumpsites. African Journal of Environmental Science and Technology, 4, 495-499.

[8] Balkhair, K. S. and Ashraf, M. A. (2016). Field accumulation risks of heavy metals in soil and vegetable crop irrigated with sewage water in western region of Saudi Arabia. Saudi Journal of Biological Sciences, 23, 32-44.

[9] Chiroma, T. M., Ebewele, R. O. and Hymore, F. K. (2014). Comparative assessment of heavy metal levels in soil, vegetables and urban grey waste water used for irrigation in Yola and Kano. International Refereed Journal of Engineering and Science, 3, 01-09.

[10] Cortez, L. A. S. and Ching, J. A. (2014). Heavy metal concentration of dumpsite soil and accumulation in Zea mays (corn) growing in a closed dumpsite in Manila, Philippines. International Journal of Environmental Science and Development, 5, 77- 80.

[11] Helmenstine, A. M. (2014). Heavy metals definition. About.com. http://chemistry.about.com/od/chemistry glossary/g/Heavy-Metal-Definition.htm.

[12] Ideriah, T. J. K., Harry, F. O., Stanley, H. O. and Igbara, J. K. (2010). Heavy metal contamination of soils and vegetation around solid waste dumps in Port-Harcourt, Nigeria. Journal of Applied Science and Environmental Management, 14, 101-109.

[13] Imasuen, O. I. and Omorogieva, O. M. (2013). Sources and environmental implication of heavy metals pollution in plants grown around contaminated site in Edo State, Nigeria. Research Journal in Engineering and Applied Sciences, 2, 385-391.

[14] Kabata-Pendias, A. (2011). Trace Elements in Soil and Plants, 4th edn.; Taylor \& Francis: Boca Raton, FL, USA.

[15] Kibria, G. 2016. Trace metals/heavy metals and its impact on environment, biodiversity and human health-A short review. 5p. DOI: 10.13140/RG.2.1.3102.2568.

https://www.researchgate.net/publication/266618621

[16] Kibria., G., Haroon, A. K. Y., Nugegoda, D. and Rose, G. (2010). Climate Change and ChemicalsEnvironmental Biological aspects. 472pp.

[17] Kibria G, Hossain M M, Mallick D, Lau TC, Wu R. (2016a). Monitoring of metal pollution in waterways across Bangladesh and ecological and public health implications of pollution. Chemosphere, 165, 1-9.

[18] Kibria, G., Hossain, M. M., Mallick, D., Lau, T. C and Wu, R. (2016b). Trace/heavy metal pollution monitoring in estuary and coastal area of the Bay of Bengal, Bangladesh and implicated impacts. Marine Pollution Bulletin., 105, 93-402.

[19] Koyuncu, F., Çetinbaş, M. and Ibrahim, E. (2014). Nutritional constituents of wild-grown black mulberry 
(Morus nigra L.). Journal of Applied Botany and Food Quality, 87(1), 93-96.

[20] Lenntech, B.V. (2014). Water treatment solutions. Delft, The Netherlands. http://www.lenntech.com/.

[21]Li, Q., Chen, Y., Fu, H., Cui, Z., Shi, L., Wang, L. and Lui, Z. (2012). Health risk of heavy metals in food crops grown on reclaimed tidal flat soil in the Pearl River Estuary, China. Journal of Hazardous Materials, 227-228, 148-154.

[22] Makanjuola, O. M., Ajayi, A. B., Mathew, K. and Makanjuola, J. O. (2013). The proximate composition and mineral contents of three plantain cultivars harvested at matured green level. International Journal of Innovation in Biosciences, 3, 23-26.

[23] Maplandia (2016). Uyo Map-Satallite Images of Uyo Map. Maplandia.com.google maps world gazetteer. http://www.maplandia.com/nigeria/akwaibom/uyo/uyo . Retrieved 14-11-2016.

[24] Nolan, K. (2003). Copper toxicity syndrome. Journal of Orthomolecular Psychiatry, 12, 270-282.

[25] Odenigbo, M. A., Asumugha, V. U., Ubbor, S., Nwauzor, C., Otuonye, A. C., Offia-Olua, B. I., et al. (2013). Proximate composition and consumption pattern of plantain and cooking banana. British Journal of Applied Science and Technology,3, 10351043.

[26] Okareh, O. T., Adeolu, A. T. and Adepoju, O. T. (2015). Proximate and mineral composition of plantain (Musa Paradisiaca) wastes flour; a potential nutrients source in the formulation of animal feeds. African Journal of Food Science and Technology, 6, 5357.

[27] Oko, A. O., Famurewa, A. C. and Nwaza, J. O. (2015). Proximate composition, mineral elements and starch characteristics: study of eight (8) unripe plantain cultivars in Nigeria. British Journal of Applied Science and Technology, 6, 285-294

[28] Okoronkwo, N. E., Ano, A. O., and Onwuchekwa, E. C. (2005) Environment, health and risk assessment: A case study of the use of an abandoned municipal waste dumpsite for agricultural purposes. African Journal of Biotechnology, 4, 1217-1221.

[29] Okoronkwo, N. E., Onyekwere, E. C. and Eze, S. O. (2015). Dry season assessment of portable quality of Okpuruala stream in Okoko Item, Bende LGA of Abia State, Nigeria. Journal of Environment Protection and Sustainable Development, 1, 23-28.
[30] Olufunmilayo, O. O., Oludare, A. H. and Oluwatoyin, D. (2014). Determination of concentrations of heavy metals in municipal dumpsite soil and plants at Okeogi, Iree, Nigeria. International Research Journal of Pure \& Applied Chemistry, 4, 656-669.

[31] Onwuka, G. I. (2005). Food Analysis and Instrumentation: Theory and Practice. Naphthali Publishers Ltd., Lagos, Nigeria. Pp 136-140.

[32] Podsiki C. 2008, "Heavy metals, their salts, and other compounds", AIC News, November, special insert, pp. $1-4$.

[33] Rim-Rukeh, A. (2012). Uptake of heavy metals by Okro (Hibiscus esculentus) grown on abandoned dump sites in Effurun, Nigeria. Journal of Emerging Trends in Engineering and Applied Sciences, 3, 640-644.

[34] Tanee, F. B. G. and Eshalomi-Mario, T. N. (2015). Heavy metal contents in plants and soils in abandoned solid waste dumpsites in Port Harcourt, Nigeria. Research Journal of Environmental Toxicology, 9, 342-349.

[35] Ukpong, E. C., Antigha, R. E. and Moses, E. O. (2013). Assessment of heavy metals content in soils and plants around waste dumpsites in Uyo metropolis, Akwa Ibom State. The International Journal of Engineering and Science, 2, 75-86.

[36]Zou, Y., Ma, K. and Tian, M. (2015). Chemical composition and nutritive value of hot pepper seed (Capsicum aпnиum) grown in Northeast Region of China. Food Sci. Techno., Campinas, 35, 659-663. 